\title{
O MST e a questão agrária
}

\section{ENTREVISTA COM JOÃO PEDRO STÉDILE}

$N$ A PREPARAÇÃo do dossiê Questão Agrária, EstUdOS AVANÇADOS julgou indispensável recolher um depoimento do principal coordenador do Movimento dos Trabalbadores Rurais Sem Terra, João Pedro Stédile, pela importância e amplitude da ação do MST no pais. Por isso, no dia 27 de agosto, Stédile nos deu uma entrevista, em que participaram o professor Alfredo Bosi e os jornalistas Marco Antônio Coelho e Dario Luis Borelli.

Nesse depoimento, respondendo às perguntas, Stédile fez uma exposição a respeito do pensamento do MST sobre a politica governamental nessa questão, não aceitando que ela esteja realizando uma verdadeira reforma na estrutura fundiária do Brasil. Indicou que o MST está de acordo com as normas constitucionais sobre a reforma agrária, deu informacões sobre a estrutura e o trabalho do MST, e a respeito do relacionamento deste com a Igreja, bem como sobre outros questionamentos da opinião pública a propósito da conduta dos sem-terra.

Apresentamos a seguir um resumo das declarações do coordenador do MST.

\section{A formação de um militante}

ESTUDOS AVANÇADOS - O senhor poderia dar inicialmente alguns elementos de sua biografia, de sua formação como militante da causa da reforma agrária no Brasil?

João Pedro Stédile - Sou descendente de imigrantes italianos, pelos avós dos dois lados. Eles migraram, como pobres camponeses, para Antonio Prado, no Rio Grande do Sul. Criei-me nesse ambiente e duas coisas influíram na minha formação pessoal: o espírito de trabalho, isto é, de que tudo na vida se ganha trabalhando, e a presença da Igreja Católica. Em geral, as mães italianas estimulavam sempre os filhos a estudar e a não se conformarem com aquela resignação de serem camponeses. Colocavam isso em nossas cabeças e veio daí meu amor ao estudo.

Fiz o primário no interior, trabalhando na roça. Minha mãe queria que eu fosse padre. Cursei o ginásio interno com os capuchinhos, saí, voltei para o interior. Fiz o $2^{\circ}$ grau ainda morando no interior e depois mudei para Porto Alegre, para fazer a faculdade e procurar emprego. Estudava à noite, trabalhava de dia em várias atividades, inclusive como padeiro. Até que lá pelo $3^{\circ}$ ano prestei concurso para a Secretaria da Agricultura, o que aumentou ainda mais meus laços com a agricultura. Quando me formei em Economia na PUC-RS, continuei na Secretaria da Agricultura. Depois tive a oportunidadede conseguir uma bolsa e fui fazer pós-graduação no México. Estudei na Universidade Nacional Autônoma do México (UNAM) 
e lá havia uma legião de exilados sul-americanos. Era um centro latino-americano de grande efervescência ideológica e sempre aberto aos temas contemporâneos.

Voltei e continuei trabalhando na Secretaria da Agricultura. Minha volta coincidiu com o processo de redemocratização do país e com o surgimento das primeiras lutas. Fui trabalhar no Sindicato dos Trabalhadores Rurais de Bento Gonçalves, que era o sindicato mais forte na época - o primeiro que retomava as lutas combativas no interior, com as quais eu tinha muita ligação pelas origens familiares, pois meus parentes, a maioria deles, se dedicavam à produção de uva. Eu conhecia essa questão e fui trabalhar com eles, fazendo um trabalho de economia e de pedagogia popular, para tentar entender o processo de exploração que eles sofriam como pequenos produtores. Organizamos grupos de famílias e calculamos o custo da produção da uva. Isso nos deu elementos para calcular o custo médio na região e para poder brigar com o governo e com as empresas produtoras de vinho por um preço mais justo.

O mais importante, porém, era o processo de conscientização dos produtores, que começavam a se dar conta de quanto custava produzir e de onde é que vinha o resultado do trabalho deles. Era muito engraçado, pois a maioria dos camponeses estranhava quando se colocava o custo da mão-de-obra. Diziam: "Mas como, a mão-de-obra é minha!". E era justamente ali que residia o segredo da produção. Estavam tão anestesiados que não acreditavam que se deveria colocar no custo o valor do trabalho, achavam que aquilo era uma obrigação. Por isso é que foram tantos anos explorados.

Entre 1978 e 1979, os camponeses começaram a perder o medo de lutar contra o governo. Embora tenha sido criada em Goiânia, em 1975, a ação da Comissão Pastoral da Terra (CPT) só se consolidou no Rio Grande do Sul em 1978. A Igreja era muito conservadora naquela região. Tanto é assim que, nos idos de 1962 e 1964, voltávamos da roça mais cedo para pegar as famosas missas das $18 \mathrm{~h}$, transmitidas por todas as rádios católicas, durante as quais rezávamos o terço ajoelhados para afastar o comunismo. Acho que de tanto rezar o terço contra os comunistas acabei também virando um deles... De certa forma, a CPT resgatou o pecado cometido pela Igreja contra os camponeses, indicando que, a partir da Teologia da Libertação, era necessário conscientizar e organizar os camponeses para lutarem pelos seus direitos. Como eu tinha uma vinculação de família com a Igreja Católica, comecei também a participar da CPT.

Houve, em 1979, um conflito de terra no Rio Grande do Sul. Com exceção do velho PCB, toda a esquerda da região dizia que lá não havia problema de terra. Foi um conflito numa área indígena, uma das últimas do Rio Grande, na famosa reserva indígena do Nonoai, que é dos índios Caigangs. Essa área tinha sido historicamente ocupada por pequenos posseiros, estimulados até por políticos. Havia uns 10 mil hectares no município Nonoai, no extremo norte do Rio Grande, fronteira com Santa Catarina, e a área estava toda ocupada por pequenos posseiros, agricultores que sonhavam um dia legalizar aquelas posses. Havia dentro da área, 
incrustrada no meio do mato, uns 200 a 300 índios que sobreviviam em situação de mendicância, pois os próprios pequenos agricultores os sustentavam.

Com o processo de conscientização da causa indígena, os Caigangs de todo Sul se organizaram, levaram gente do Paraná e de Santa Catarina e fizeram uma bela ocupação contrária, ou seja, reocuparam a terra que era deles por lei, que estava legalizada, e com isso expulsaram os pequenos agricultores. Expulsaram de uma maneira violenta, claro, pois num dia tiraram todos da área. Eram umas 1.400 famílias de pequenos agricultores, foi um problema social tremendo.

Comecei a trabalhar com esses agricultores. Parte deles queria voltar para a área, enfrentar os índios, matar os índios. Desde o início tínhamos uma concepção contrária: o problema não era retomar a terra dos índios, pois tinham seus direitos e nós também tínhamos direito à terra. Mas não essa terra, porque era deles, historicamente deles, independente do papel que garantia a propriedade.

O governo acenou com a possibilidade de parte dos agricultores ir para outro lugar. O Incra montou uma grande operação para levá-los para Terra Nova, no Mato Grosso. Mas cerca de 500 famílias se recusaram. A cultura do gaúcho diz: "Lugar de gaúcho é no Rio Grande... daqui ninguém nos tira". Com essa decisão, falei: "Se vocês querem mesmo ficar aqui, vamos nos organizar". Descobri onde havia latifúndios, porque, como dizia o Estatuto da Terra, o governo era obrigado a desapropriar os latifúndios para fazer a reforma agrária.

Como estávamos no período do general Figueiredo, com todo aquele clima de ditadura militar, eu fazia reuniões praticamente sigilosas com os agricultores. No dia 7 de setembro de 1979, resolvemos ocupar dois latifúndios. Eram terras públicas que o governo escondia da opinião pública e arrendava ilegalmente a dois latifundiários. Ambas eram reminiscências de um projeto de reforma agrária do Leonel Brizola, realizado em 1962. Eram parte de uma fazenda que o Brizola havia desapropriado. Quando veio a ditadura em 1964 ainda não se tinha completado o processo de distribuição das terras da fazenda. $O$ que o governo do Estado e os militares fizeram? Pegaram duas dessas áreas grandes, uma de 1.400 hectares e outra de $\mathbf{1 . 7 0 0}$ hectares e arrendaram para filiados políticos, fazendeiros, que ocuparam as áreas ilegalmente. Fizemos a ocupação da Granja Macali e da Granja Brilhante, com as famílias originárias do conflito com os índios.

Por causa talvez da experiência do Master - do Brizola e do PTB - autodenominado Movimento dos Agricultores Sem Terra, a imprensa local logo proclamou: "Os sem-terra voltaram, os sem-terra voltaram...". Aí pegou. Foi a imprensa que deu o nome de movimento sem-terra. Não foram os próprios agricultores. Essas duas ocupações foram as que acabaram dando origem ao MST, em $7 \mathrm{de}$ setembro de 1979. Em três ou quatro meses os agricultores foram assentados e foi uma baita vitória.

A fazenda Sarandi era de propriedadede de um grande latifundiário uruguaio, que possuía lá no Rio Grande do Sul 24 mil hectares. O Brizola era governador 


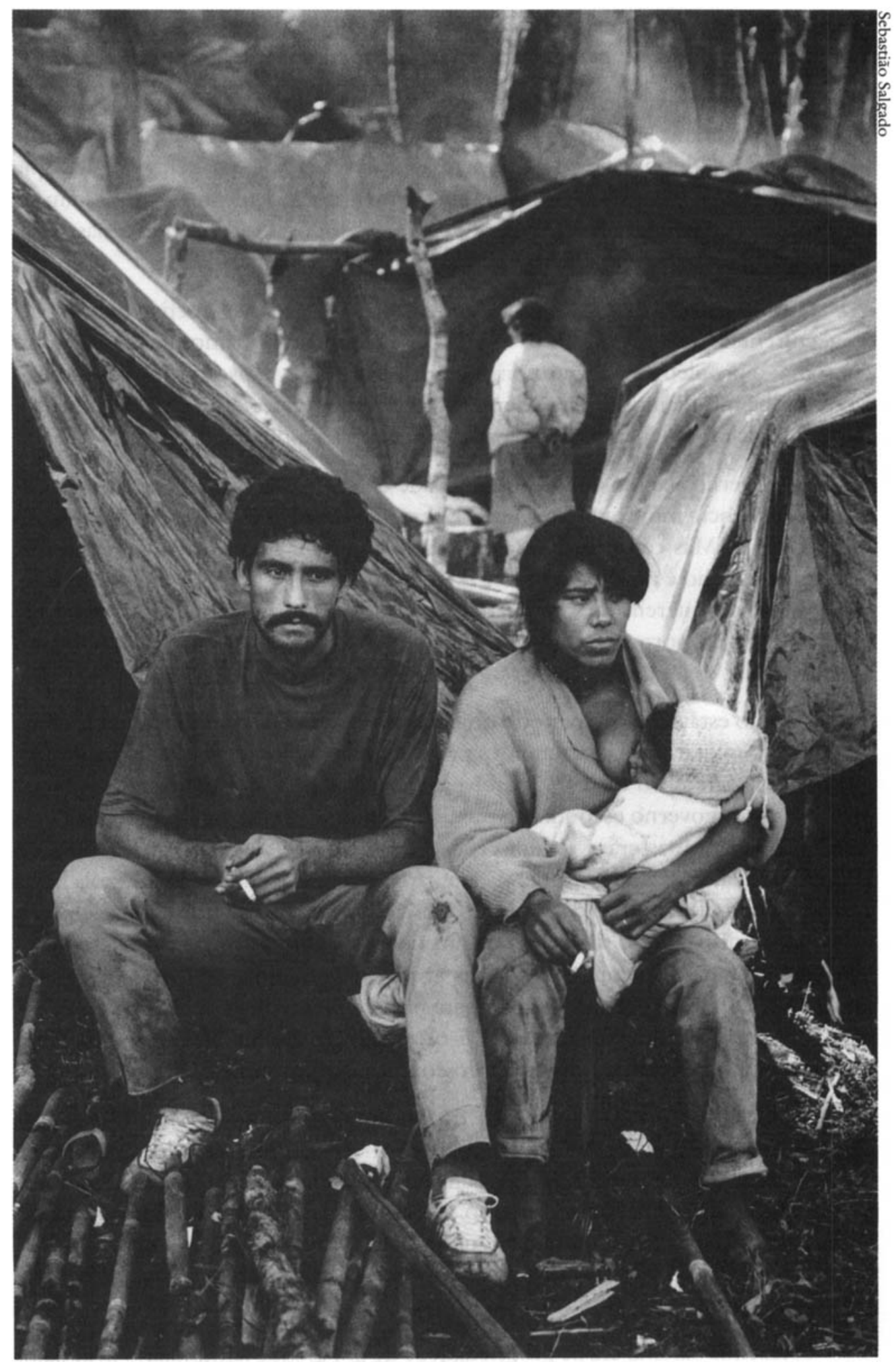

Ocupação da Fazenda Gracometi, latıfúndıo de 83 mil hectares em áreas contínuas, Paraná, 1996. 
do Estado, de 1958 a 1962. Lá por volta de 1961, surgiu o Master, que ocupou essa fazenda, com toda essa motivação de que era uma família de uruguaios, que não morava e não tinha nem boi lá, por especulação imobiliária e pelo fato de ter muito pinheiro. O Brizola, numa medida justa e com aquela visão que ele tinha, fez um governo muito popular, de esquerda. E a origem da popularidade que o Brizola tem até hoje no Rio Grande. Muita gente imagina que o Brizola tem fama pelo seu caudilhismo ou porque controla o PDT, de cima para baixo no Rio Grande. Na verdade, o PDT do Rio Grande tem pouco a ver com o Brizola, mas o carinho que o povo gaúcho tem ao Brizola é em função desse governo que ele fez. Todas as iniciativas de cunho popular e democrático devem-se a esse governo. Foi ele, por exemplo, que desapropriou a ITT, que controlava nossa telefonia, e criou a Companhia Riograndense de Telecomunicações. Uma das medidas populares que ele tomou na época foi quando o Master ocupou a fazenda Sarandi. Ele imediatamente se solidarizou com os ocupantes e depois utilizou a legislação estadual para desapropriar. Só que, como a fazenda era muito grande, não deu tempo de fazer todo o procedimento de assentamento. Ele conseguiu assentar apenas na metade da fazenda. Em 1962, subiu para o governo o Meneghetti, que era do PSD, conservador, e este freou o processo de distribuição das terras da fazenda Sarandi, pois distribuiu parte dela a amigos e correligionários do PSD.

\section{A situação dos assentamentos}

ESTUDOS AVANÇADOS - Qual seu balanço sobre os assentamentos já consolidados pelo MST? A informação que temos é que alguns prosperam e outros não. Que fatores determinam essa diversidade nos resultados?

J. P. Stédile - Em primeiro lugar, consideramos que genericamente deve haver em torno de $150 \mathrm{mil}$ famílias em projetos de assentamentos. $O$ governo costuma usar dados maiores, de $\mathbf{2 8 0}$ mil, 300 mil famílias. Na verdade, aí se soma toda a história do Brasil, desde a época de Getúlio Vargas, que foi o primeiro que fez colonização oficial, até nossos dias. Sobretudo aglutina projetos de colonização, que nada têm a ver com assentamento. Há consenso que nos assentamentos mesmo temos em torno de 150 mil famílias, nos últimos 15 anos. Todos esses assentamentos foram resultado de algum tipo de luta. Em nenhum deles o governo tomou a iniciativa.

E importante esclarecer que não consideramos esses assentamentos como um processo de reforma agrária. Reforma agrária, no nosso modo de entender, seria se houvesse uma medida mais ampla e massiva que conseguisse frear a concentração da propriedade da terra e de fato distribuir a propriedade da terra. Mesmo com esses assentamentos, nesses 15 anos, o processo de concentração da propriedade da terra no Brasil continua, de maneira que não vivenciamos uma reforma agrária na sua essência. Estamos distribuindo terras apenas para resolver problemas sociais e não como uma política, um programa de reforma agrária mais ampla.

Quais as características desses assentamentos? Alguns continuam pobres, outros remediados e alguns são um sucesso. De certa forma eles reproduzem o que 
acontece na agricultura em geral. Porque, apesar de os lavradores receberem terra do governo, imediatamente se transformam em pequenos produtores rurais e passam a enfrentar todas as contradições que têm os outros pequenos produtores.

Existe, em termos gerais, a seguinte diferenciação: nos primeiros dois anos de assentamento, em geral, as famílias se preocupam em resolver seu problema de comida. Eles passam a produzir apenas para comer. Aceitamos isso, porque é praticamente uma fome histórica. De maneira que não temos nenhum assentamento em que haja fome, todo mundo come bem, o que já seria uma grande conquista numa sociedade que tem 32 milhões de pessoas que passam fome todos os dias.

Mas, passada essa etapa, o assentado pobre quer construir sua casinha e ter escola para seus filhos. O MST faz então um trabalho de conscientização e de organização para mostrar que só produzir para comer não resolve, que o agricultor precisa ter renda e para ter renda ele tem de produzir para o mercado. Nosso trabalho é identificar quais são as culturas que têm mercado e estimular que o agricultor produza para o mercado. Aí já começa a haver uma diferenciação: quem consegue entrar para o mercado local aumenta a renda, começa a se diferenciar daquele que só ficou produzindo para comer. Passados quatro, cinco, seis anos, conseguimos fazer com que eles percebam que, na realidade da agricultura de hoje, não basta também produzir só para o mercado local, e que os mercados mais organizados exigem agroindústria.

Hoje a maioria dos produtos que vêm para a mesa do trabalhador passam por um processo de agroindústria. Portanto, se o agricultor quiser aumentar sua renda e participar de um processo de desenvolvimento na sua região tem de se casar com a agroindústria. Aí ele tem dois caminhos. Ou se associa à agroindústria que já está instalada, às grandes empresas oligopolizadas - como Sadia e Perdigão na área de avicultura; ou Souza Cruz, Philip Morris, no fumo; na área de leite, Parmalat, Nestlé, enfim todos os setores que estão mais ou menos oligopolizados. $\mathrm{Ou}$, o que é um das linhas que estamos adotando, também começa a botar pequenas agroindústrias nos assentamentos.

Quem não consegue produzir grande quantidade para o mercado não tem influência no mercado, mas isso tem grande importância para ele, porque aumenta muito a renda na medida em que industrializa o produto. $O$ caso do leite é típico, as empresas compradoras de leite pagam hoje em torno de 0,16 ou 0,17 centavos $o$ litro. Tiram manteiga, fazem iogurte, botam um pouquinho de água e vendem ao consumidor a 0,60 ou 0,80 centavos o litro, além de todos aqueles benefícios. Nós, instalando um pequeno laticínio que pasteuriza o leite, sem fazer nenhum subproduto, conseguimos vender direto na cidade por 0,55 , praticamente sem nenhum custo a mais, porque o plástico é baratíssimo e o equipamento do laticínio de uma pequena agroindústria é barato. Com 10 ou 15 mil dólares é possível pasteurizar mil, cinco mil litros de leite por dia. De maneira que o pequeno agricultor só com esta máquina lá no assentamento consegue aumentar o preço do leite dele de 0,16 centavos para 0,55 , triplicando sua renda. 
Esse é o nosso esforço. Cada assentamento está num estágio diferente. Se você visitar um assentamento que ainda está no primeiro, ou segundo ano, vai ver muita pobreza, mas o agricultor está comendo. Se você visitar um assentamento mais antigo, onde já temos agroindústria, aí irá ver maravilhas. Temos laticínio, frigorífico e estamos implantando várias linhas de agroindústria. Então, a renda aumenta muito, como se vê em São Paulo, por exemplo, em Itapeva ou no município de Promissão, onde os agricultores instalaram pequenas unidades de agroindústria. Nelas a renda aumenta muito e eles conseguem ter um padrão de vida muito superior a que teriam se estivessem ganhando um bom salário na cidade.

\section{A estrutura do MST}

ESTUDOS AVANÇADOS - De certa forma o MST realiza alguma coisa semelhante às Ematers, que fazem extensão rural?

J. P. Stédile - Dividimos o Movimento por setores de atividades. Que setores há dentro do MST? O setor de educação, com um enorme contingente de companheiros que se preocupam em discutir como organizar as escolas, como dar formação às crianças e como preparar professores que dão aula nos assentamentos. Depois, temos um setor de formação política e ideológica, para preparar nossos militantes, com escolas regionais e uma escola nacional em Santa Catarina. Além disso temos um setor de comunicação, que se dedica a preparar boletins, programas de rádio para as rádios comunitárias. Nacionalmente temos o jornal Sem Terra e a revista Sem Terra. Uma home-page na Internet também faz parte desse setor de comunicação.

Há também o setor de produção, que chamamos sistema dos cooperativistas assentados. Esse setor é o que organiza as cooperativas, que estimula a cooperação agrícola nos assentamentos. A extensão rural é feita por nós mesmos para nós mesmos. Agora vamos dar um passo a mais com esse projeto do governo, o Lumiar. Como resultado da visão neoliberal para a agricultura, o governo sucateou a Embrapa e as Ematers, que estão fechando em todo país. Ficam lá poucos agrônomos desestimulados, sem nenhuma condição de trabalho. Com o projeto Lumiar, o Incra está repassando recursos para contratarmos agrônomos através de nossas cooperativas. A expectativa é que consigamos ampliar também esse trabalho de assistência técnica.

\section{ESTUDOS AVANÇADOS - Qual é o perfil dos assentados?}

J. P. Stédile - Em termos gerais, é o seguinte: $95 \%$ dos assentados eram agricultores, assalariados, filhos de pequenos agricultores ou viviam como parceiros e arrendatários. Embora haja muito desemprego na cidade, a ampla maioria dos assentados é de agricultores. Em termos de escolaridade, $65 \%$ deles têm até o $3^{\circ}$ ano primário, os adultos. Todo esforço daquele setorzinho de educação agora é justamente para os filhos ultrapassarem aquele limite dos pais. Em todos os assentamentos já temos escolas de $1^{\circ}$ grau e a nossa luta é para que os filhos dos assentados consigam chegar ao $2^{\circ}$ grau. Temos duas escolas que formam professores de $2^{\circ}$ 
grau, e uma escola técnica de administração de cooperativas, em nível de $2^{\circ}$ grau. $O$ nome da nossa escola é uma homenagem a um grande pensador do Brasil que, infelizmente, a academia não recupera - Josué de Castro.

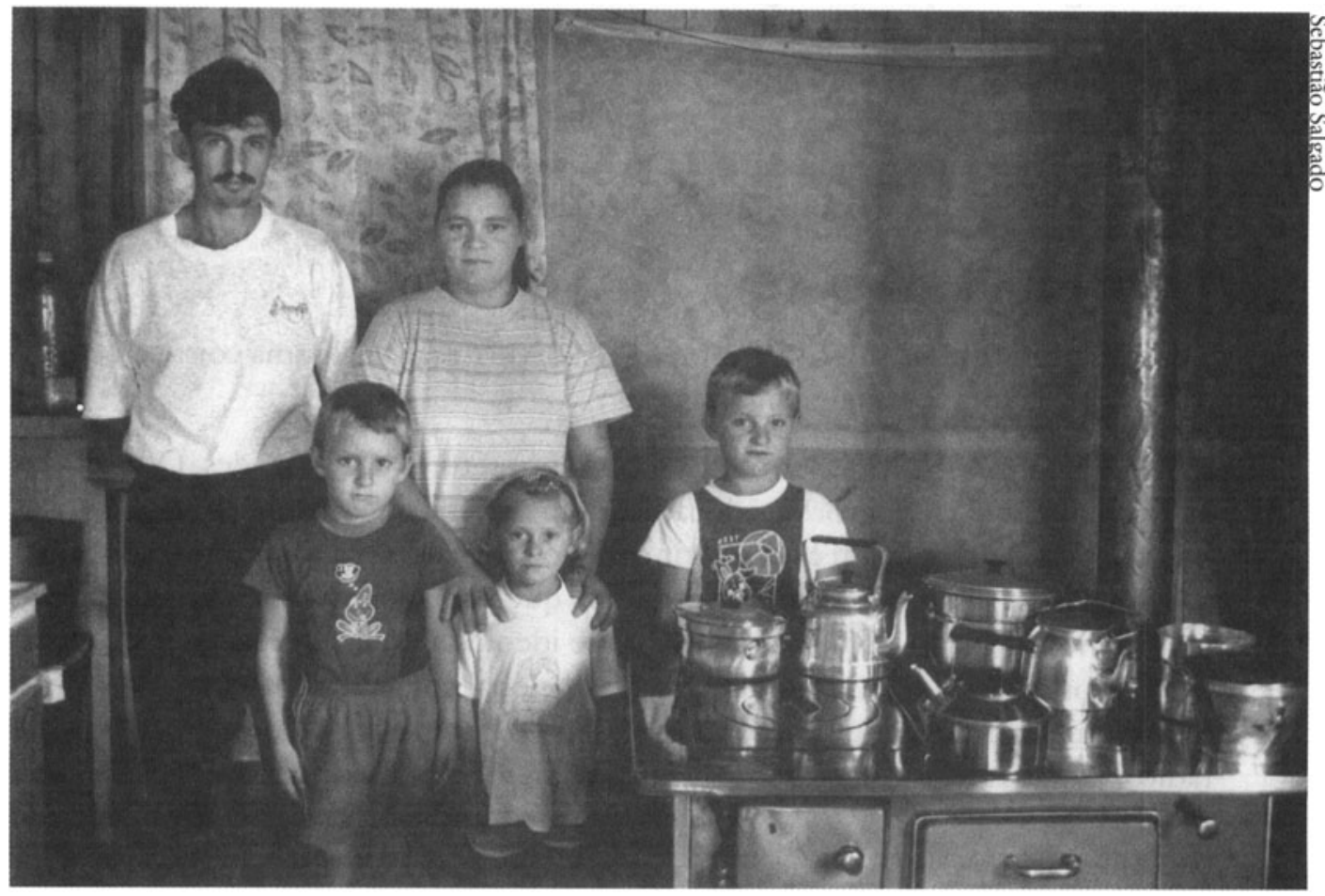

Familia no interior de sua casa no assentamento Conquista na Fronteira, Santa Catarina, 1996.

\section{O futuro da agricultura familiar}

ESTUDOS AVANÇADOS - Como o senhor vê o futuro da chamada agricultura familiar, ao lado da grande agricultura moderna? Há espaço hoje para a agricultura familiar no Brasil?

J. P. Stédile - Essa é realmente a pergunta chave, pois revela o desafio que estamos enfrentando hoje no Brasil. Também revela a grande divergência estratégica que temos com o governo Fernando Henrique Cardoso e porque o MST virou um ator político importante. Muita gente pensa que somos um ator político importante porque fazemos ações espetaculares, ou porque saímos todo dia na imprensa. Não é nada disso. A imprensa vive muito de modismo, amanhã ou depois podemos sair do noticiário da imprensa.

O que está por trás da importância política que adquirimos é a nossa divergência de fundo com o atual governo, que está implantando um novo modelo de desenvolvimento na nossa sociedade. No Brasil, só vivenciamos dois modelos de desenvolvimento: o primeiro foi aquele agroexportador até 1930 e o segundo foi aquele modelo de industrialização que vigorou de 1930 a 1980, e mudou a cara do 
nosso país. Depois de 1980, entramos numa crise econômica e as próprias elites brasileiras não encontraram saída para a crise. Com o governo Fernando Henrique Cardoso, na nossa opinião, as elites brasileiras criaram um consenso para implantar no Brasil um novo modelo de desenvolvimento. É um modelo que subordina completamente nossa economia ao capital internacional. Já não se trata mais apenas de aliança com o capital estrangeiro, como foi implantado de Kubistchek para cá, agora é subordinação. Por isso nossa economia é tratada pelo governo não mais como uma economia nacional, e os problemas daqui como problemas do povo. A economia brasileira é tratada apenas como mercado, e esse mercado pode crescer desde que seja aberto ao capital internacional, que virá aqui com suas mercadorias e com seu capital financeiro, que anda circulando no mundo inteiro.

Dessa forma, as elites criaram um novo consenso, repetindo na história do Brasil o consenso que elas criaram em torno de Getúlio Vargas. Por isso o Fernando Henrique é tão forte, representa o consenso das elites em torno de um novo modelo de desenvolvimento. Ora, nessa nova idéia das elites, marginaliza-se a economia local, marginaliza-se a agricultura. Eles justificam que a agricultura não tem mais sentido porque pesa apenas $11 \%$ no PIB, mas isso é pura manipulação estatística. Se agregarmos à agricultura a agroindústria, o peso no PIB passa a $46 \%$. Independente do peso estatístico econômico, o importante é entender que nas economias locais, nos municípios, no interior do Brasil, é a agricultura a base de toda a atividade econômica, é ela que proporciona o comércio de mercadorias naqueles municípios e é ela que pode dar sustentação a um possível salto para a indústria, porque ninguém vai botar uma fábrica de computador em Xapuri, no Acre. O que os companheiros estão fazendo lá é um fábrica para industrializar castanha. Ou seja, uma atividade vinculada diretamente com a agricultura, com o meio, com os recursos naturais abundantes.

O governo está aplicando uma política que marginaliza completamente a agricultura. Embora a economia como um todo possa crescer, porque está recebendo muita injeção de capital estrangeiro, porque está havendo desenvolvimento em setores de ponta, nossa agricultura não saiu da crise, porque não cabe mais nesse modelo de desenvolvimento. Quais são os indicadores da crise? De 1980 para cá, em 16 anos, a área cultivada aumentou $2 \%$. Somos um país de grande extensão territorial e cultivamos apenas 60 milhões de hectares! Isso é uma vergonha. E não se vê luz no fim do túnel para aumentar a área cultivada, ao contrário. O governo diz que a questão da terra hoje não é mais fundamental, que o principal é a tecnologia. Na visão do capitalista, sim, mas não na visão da população do interior. $O$ acesso à terra é fundamental para aumentar a produção. Mesmo em termos de produção agrícola, houve um aumento de $34 \%$ nesses 16 anos, segundo a Fundação Getúlio Vargas, o que revela que os produtores aumentaram a produtividade. Mas a renda dos agricultores em geral caiu $49 \%$, nesse mesmo período. Embora em 16 anos a produção agrícola tenha aumentado $34 \%$, a população nesse mesmo período cresceu quase $50 \%$. De maneira que a oferta per capita de alimentos deve ter caído também. 
Vejamos os últimos dois anos, período em que se intensificou a política neoliberal. Quais as consequências para a agricultura? Segundo estimativas oficiais do professor Guilherme Dias, quando este era do Ministério da Agricultura, 400 mil pequenos agricultores perderam suas terras nos dois anos e meio do governo Fernando Henrique. O professor Delfim Neto estima que 800 mil trabalhadores assalariados perderam emprego na agricultura no mesmo período, 200 mil no algodão, 180 mil no cacau e os outros dispersos nas demais culturas. Mesmo havendo recursos para o crédito rural, embora pequenos, o agricultor não se anima mais a pegar dinheiro no banco. Ele percebe que sua renda está diminuindo e que a cada ano o poder aquisitivo dele diminui, e ele não consegue mais pagar os juros.

Do ponto de vista das elites, do ponto de vista do modelo econômico que está sendo implantado hoje no Brasil, não cabe mais nem agricultura voltada para o mercado, nem agricultura familiar. Mas, do ponto de vista dos trabalhadores e do povo brasileiro em geral, e das necessidade de um novo modelo de desenvolvimento que leve em conta um verdadeiro desenvolvimento para o Brasil, a agricultura tem um papel fundamental, e a pequena agricultura ainda mais. E a pequena agricultura que produz alimentos, é ela que tem condições de abastecer o mercado local e de resolver dois graves problemas de nossa sociedade, que esse novo modelo do Fernando Henrique só vai agravar - o do desemprego e o da violência na cidade.

Hoje temos 18 milhões de desempregados no Brasil, segundo o presidente da Federação do Comércio de São Paulo, Abraham Szajman. Como resolver esse problema? Colocando fábrica de automóvel, como diz o governo? Isso é uma idiotice. Eu estava lendo nos jornais que a própria população de Rezende (RJ) está reclamando porque a Volkswagem foı lá, instalou-se, está fazendo os carros e não aumentou o número de empregos. A sociedade brasileira só vai conseguir resolver o problema do desemprego se apelar para a agricultura. Segundo o próprio Abaham Szayman, 65\% dos 18 milhões de desempregados têm até o $3^{\circ}$ ano primário. Em São Paulo, não aceitam mais porteiro de prédio com menos do primário completo, que é a $8^{2}$ série. Então não adianta mais migrar para a cidade porque nessa não tem emprego.

O segundo problema grave é o da marginalidade nas cidades, da violência provocada pelo êxodo rural. Nossas cidades se tornaram inadministráveis. O plano do governo, dito por eles, é que espera na próxima década reduzir a população rural para $4 \%$ ou $5 \%$. Isso significa que em 10 anos teremos mais de 20 milhões de pessoas que virão para a cidade. Isso vai transformar nossas cidades em um absurdo, e é por isso que tenho dito que se não conseguirmos mudar esse modelo as cidades brasileiras vão virar uma Colômbia. Não tendo alternativa para essa população, ela busca alternativas individuais e as alternativas individuais de sobrevivência são pequenos furtos, banditismo, prostituição e narcotráfico. Ou seja, a população reproduz as mazelas do capitalismo e fere moralmente nossa sociedade criando muitas dificuldades para recompor o que os sociólogos chamam de tecido social e a capacidade da própria sociedade de reagir e enfrentar seus problemas. 


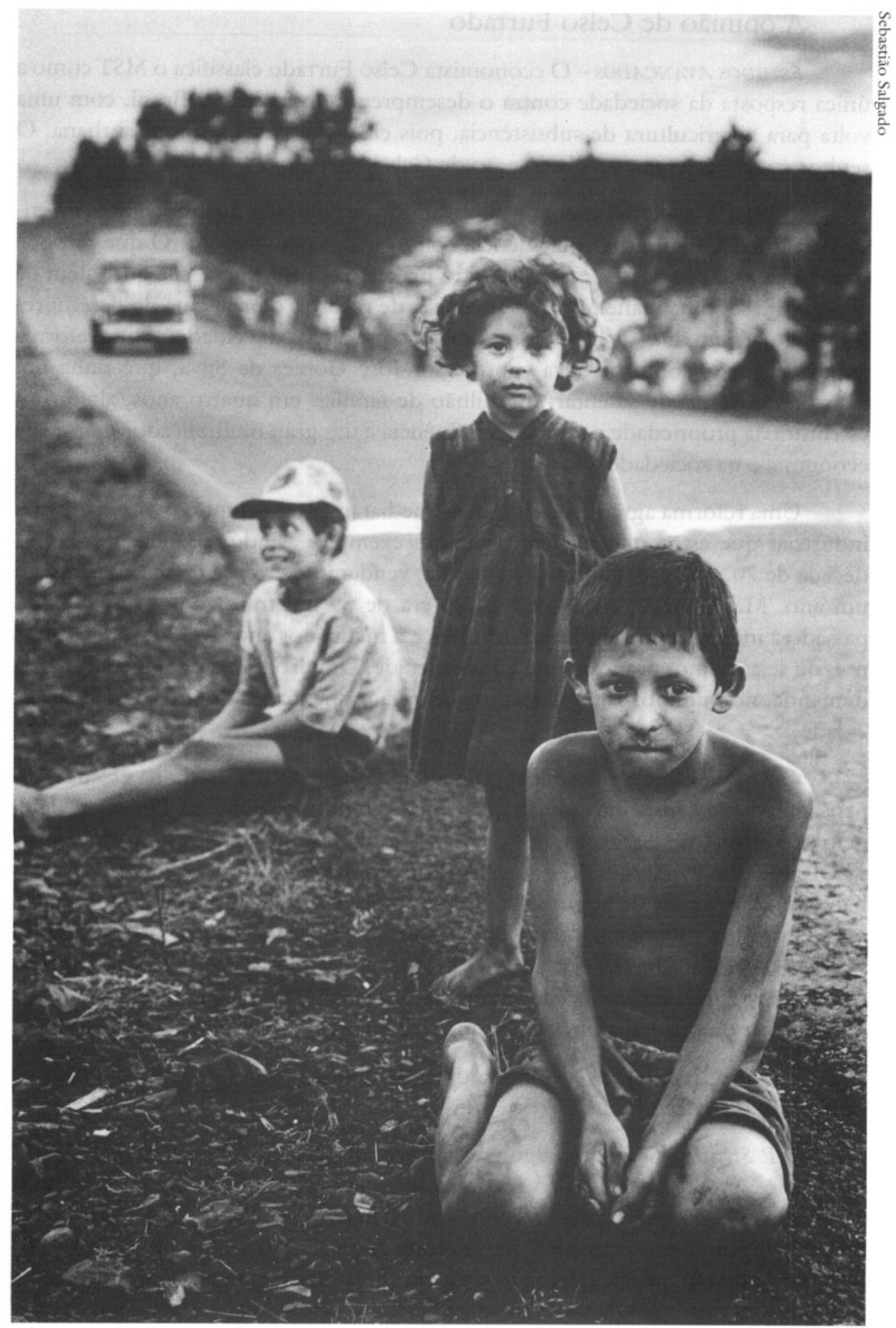

Menina à margem da BR-158, que liga Laranjeiras do Sul a Chopınzinbo, no Paraná, 1996 


\section{A opinião de Celso Furtado}

ESTUDOS AVANÇADOS - O economista Celso Furtado classifica o MST como a única resposta da sociedade contra o desemprego em massa no Brasil, com uma volta para a agricultura de subsistência, pois ela é preferível à miséria urbana. $O$ senhor concorda com essa observação de Celso Furtado?

J. P. Stédile - Obviamente ficamos muito orgulhosos quando vimos, na entrevista que ele deu, uma coincidência com o nosso pensamento. O que se pode detalhar mais além desse pensamento do professor Celso Furtado é que, além da agricultura ser uma maneira barata, massiva, de resolver o problema do desemprego, ela atuará em duas direções para resolver o problema das cidades. Uma reforma agrária massiva, como pregava o professor José Gomes da Silva, que tinha um plano de governo de assentar um milhão de famílias em quatro anos, alteraria a estrutura da propriedade e.teria uma influência e um grau multiplicador grande na economia e na sociedade.

Uma reforma agrária massiva ativa imediatamente o emprego na cidade, nas indústrias que estão ociosas. Vou citar um exemplo: a indústria de tratores. $\mathrm{Na}$ década de 70, no boom do milagre agrícola, vendemos cerca de 65 mil tratores em um ano. Mas a média na década de 70 era de 39 mil tratores por ano. $O$ ano passado a indústria vendeu 15 mil tratores e a média dos anos 90 está sendo de 23 mil, ou seja, caímos praticamente para a metade. Um programa de reforma agrária demanda, no mínimo, 100 mil tratores anuais, o que geraria muitos empregos na cidade.

Outro viés que a reforma agrária atende, e que talvez esteja na essência do pensamento de Celso Furtado, é que hoje, segundo pesquisa da Unicamp, feita pelo professor José Graziano, nos pequenos e médios municípios - Lins, Promissão, Presidente Prudente e Teodoro Sampaio, por exemplo-, de menos de 50 mil habitantes, a metade da população, embora more na cidade, está vinculada à agricultura. Embora tenhamos uma população pobre, desempregada, urbanizada, se fizermos a reforma agrária essa população volta a se vincular ao campo por causa de sua origem. Ainda assim $50 \%$ dessa população dependem da agricultura, quer por ser bóia-fria ou porque a oficina em que trabalha tem vínculos com a agricultura.

ESTUDOS AVANÇADOS - Como a diversidade das regiões do país se reflete na orientação do MST?

J. P. Stédile - Seguimos algumas linhas políticas gerais. Primeiro, em termos de cultura, procuramos não só reconhecer como também estimular as culturas locais. A televisão está causando um grande desastre na cultura do povo do interior. No assentamento do MST na Fazenda Macaxeira, na área do massacre de Carajás, onde a temperatura chega a 40 graus, as meninas vestem a mesma coisa que as nossas meninas nos assentamentos no Rio Grande do Sul. Todo mundo quer falar igual ao que sai na novela. Nós, como linha política, do ponto de vista da cultura, procuramos revalorizar a cultura local, a cultura dos antepassados. 
Temos uma linha política que tende a respeitar a diversidade regional, mas que de certa forma $e ́$ universal. Achamos que para a agricultura dar certo, independente da região, temos que estimular a cooperação agrícola. É impossível o sujeito progredir na vida e se desenvolver socialmente se continuar simplesmente como pequeno agricultor. Não queremos reproduzir o Jeca Tatu, mas um homem novo capaz de produzir mercadorias, que garanta o futuro para sua família e que se integre nos benefícios da sociedade como um todo. Para isso só há um caminho, é o que nós chamamos de cooperação agrícola, ou seja, ele tem de se juntar com seus vizinhos, tem de fazer alguma atividade em conjunto com outros companheiros. Que atividade ele deve fazer em conjunto? Depende da consciência política e da realidade social de cada região. Essa cooperação agrícola vai desde atividades simples como um mutirão, embora o resultado da colheita seja num lote individual, até formas mais complexas de cooperação agrícola. Temos em torno de 400 associações de agricultores assentados que compram máquinas em conjunto, compram gado em conjunto, ou vendem mercadoria em conjunto. Também temos 55 cooperativas onde tudo é coletivo, as nossas CPAs. Trata-se de um número reduzido porque exige um grau de capitalização maior e um nível de consciência política e ideológica maior.

A terceira linha política que adotamos indica que os agricultores devem priorizar o mercado local. $\mathrm{O}$ mercado dos produtos alimentícios está muito ligado não só aos recursos que a natureza local proporciona, como aos hábitos e à cultura local. Isso também nos garante que os assentamentos estejam vinculados à realidade regional. Essa é mais ou menos a nossa política para todos eles.

Leite sendo submetido ao processo de pasteurizą̧̃ão em assentamento no Rio Grande do Sul.

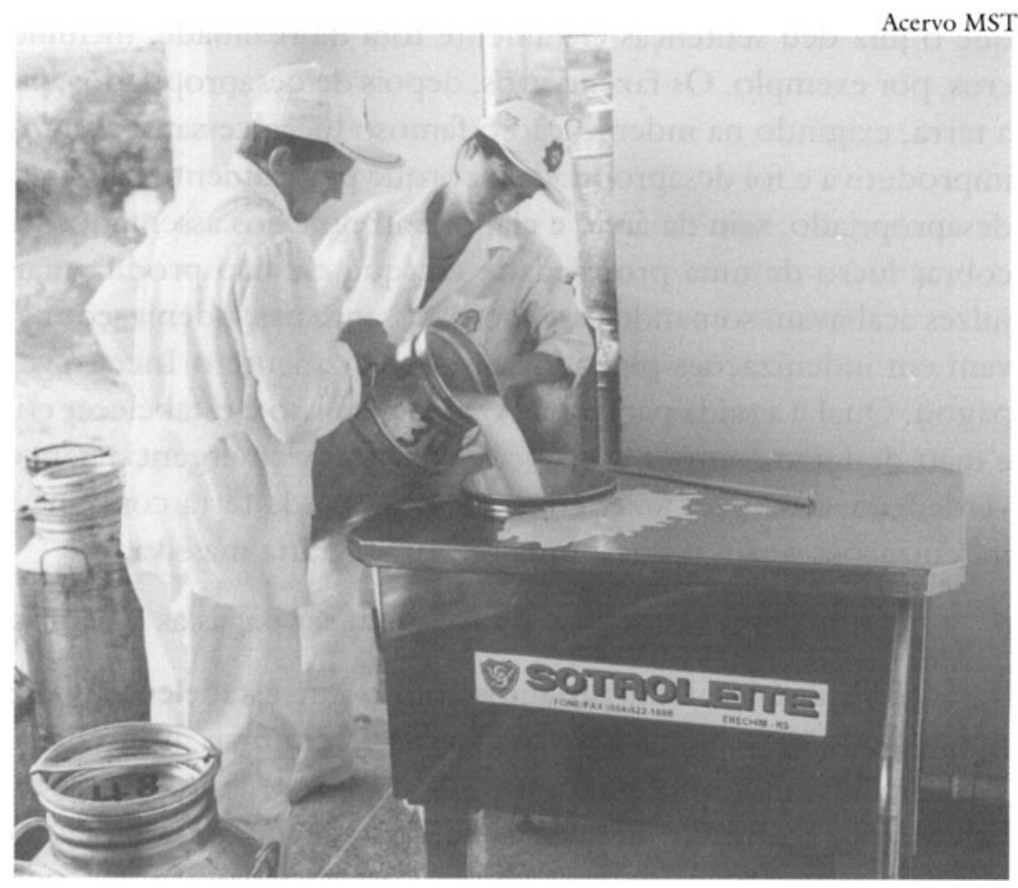




\section{O preço da terra e as desapropriações}

ESTUDOS AVANÇADOS - Há informações de que o preço da terra caiu nos últimos anos. Isso é verdade? Também se diz que nas desapropriações feitas pelo próprio Incra há superavaliação. O que deveria mudar nas normas governamentais com relação a esse problema da desapropriação de terras?

J. P. Stédile - Como estamos numa casa da academia, quero fazer um devaneio intelectual. $O$ governo tem feito propaganda de que o preço da terra caiu, e de fato caiu, segundo todas as pesquisas. O governo usa esse dado da realidade como efeito de propaganda, que o preço da terra teria caído por causa do plano Real, porque o plano Real combateu a especulação, porque o plano Real estabilizou a moeda... Não é verdade, na nossa interpretação ou na minha interpretação particular. Estudando como se forma o preço da terra em $O$ Capital, de Marx, vê-se que o preço da terra não é nada mais, nada menos, que a renda da terra acumulada. No momento em que vende o direito de explorar a terra, o fazendeiro na verdade está vendendo a expectativa de lucro que aquela terra pode dar. Ora, se a renda agrícola, como comentei antes, vem caindo nos últimos 10 anos, como mediu a própria Fundação Getúlio Vargas, é óbvio que Marx tinha razão. O preço da terra no Brasil, em termos reais, deve ter caído $49 \%$. Aí é que está a explicação real: se a renda agrícola e a renda da terra caíram, então o preço por hectare tende a cair.

Sobre as indenizações do Incra, há dois aspectos. Primeiro, a corrupção. Em todos os casos de superavaliação, houve corrupção dos funcionários do Incra, que fizeram um laudo técnico dando um preço da terra superior ao médio da região. Há outros casos em que houve corrupção do Judiciário, também comprovada, em que o juíz deu sentenças claramente fora da realidade, incluindo cessação de lucros, por exemplo. Os fazendeiros, depois de desapropriados, paravam de explorar a terra, exigindo na indenização o famoso lucro cessante. Ora, se a propriedade é improdutiva e foi desapropriada é porque praticamente não havia lucros. Se ele foi desapropriado, saiu da área, e ela foi entregue aos assentados, ele então não pode cobrar lucro de uma propriedade em que ele não produz mais. No entanto, os juízes acabavam somando esse lucro cessante nas indenizações, que se transformavam em indenizações gigantescas, que felizmente o Incra teve bom senso e não pagou. Qual é a saída para isso? A saída para isso é estabelecer critérios mais dignos e mão-de-ferro contra a corrupção, mas isso é emergência para evitar falcatruas. A verdadeira saída para fazer com que o preço da terra continue baixando e que as indenizações sejam justas é uma reforma agrária massiva.

\section{ESTUDOS AVANÇADOS - Como devem ser pagas as desapropriações?}

J. P. Stédile - Concordamos com o que estabelece a Constituição. Embora muita gente diga que o Estatuto da Terra era mais avançado, e de fato era, se o governo fizer um processo massivo de desapropriação deve-se respeitar o que estabelece a Constituição. Por ela as benfeitorias devem ser pagas em dinheiro, pois presume-se que foi fruto de trabalho. Portanto, é uma medida justa. Mas é preciso um bom levantamento. Tem de haver um mínimo de critério técnico dos agrôno- 
mos, de quem faz a vistoria, para não se concordar, como acontecia nessas supervalorizações, quando o fazendeiro dizia que tinha plantado mogno, pinheiro, que são árvores que, para virarem adultas, levam 100, 200 anos. A Constituição é clara, estabelece o pagamento à vista e em dinheiro das benfeitorias, que são fruto de trabalho.

A terra é paga em 15 anos, em títulos da dívida pública. Assim ele vai resgatar em 15 prestações, o que também é um critério justo, porque a sociedade precisa de tempo para aumentar a produção e repor aqueles valores. Esses critérios nós aceitamos.

\section{Respeito à propriedade produtiva}

ESTUDOS AVANÇADOS - O senhor julga que não deve haver reforma agrária nos latifúndios produtivos?

J. P. Stédile - O Estatuto da Terra classifica as explorações agrícolas no Brasil como: 1) minifúndios, as propriedades que não conseguiram progredir economicamente; 2 ) empresas agrícolas, as propriedades que conseguiram progredir e produziram muito; 3 ) os latifúndios, as propriedades que produziam aquém do seu potencial. Nessa definição de latifúndio já se subentendia o latifúndio improdutivo.

Com a nova lei agrária de 1993, os deputados foram mais burros, ou menos espertos, porque poderiam ter utilizado a mesma terminologia do Estatuto da Terra, que já era mais ou menos consenso, era lei. Criaram um outro conceito, aí gerou essa confusão. Qual o conceito que eles criaram? Que, agora, as propriedades sejam classificadas de maneira diferente no cadastro do Incra, e para efeito da lei são assim classificadas: primeiro, pequenas propriedades de até três módulos rurais, que o Incra define por portaria, o que dá mais ou menos 50 hectares. Mas a pequena propriedade pode ser pequena propriedade produtiva ou pode ser improdutiva, ou pode até ser uma chácara só para lazer, e é improdutiva. Por isso, a classificação do Estatuto da Terra era mais precisa. Depois a segunda classificafã̃omédia propriedade. Quais são as médias propriedades? Nem diz se é produtiva ou improdutiva. Diz propriedades de três até 15 módulos, que o Incra estabelece por região, grosso modo chegam mais ou menos até 500 hectares. A terceira classificafã̃ 0 a grande propriedade, acima de 15 módulos, sendo que as grandes propriedades podem ser produtivas e improdutivas. Depois a Constituição diz que são passíveis de desapropriação para reforma agrária todas as grandes propriedades, acima de 500 hectares, que sejam improdutivas. Todos os demais tipos de propriedade, a pequena, a média e a grande estão fora da desapropriação, não podem ser desapropriadas.

Aí vem o outro artigo, que, de novo, gerou polêmica. Como se classifica a propriedade improdutiva? A Constituição diz o seguinte: a propriedade tem que cumprir sua função social, que é a de garantir trabalho, de não ter trabalho escravo e seguir critérios de produtividade que o Incra vai estabelecer por região. Aí remete para uma legislação complementar que depende da boa vontade e de celeumas 
judiciais, porque o juiz pode estabelecer um novo critério de produtividade. É por isso que muitos fazendeiros, que não gostam da desapropriação, entram na Justiça alegando que aquele critério classificou sua propriedade como improdutiva quando ela é produtiva.

ESTUDOS AVANÇADOS - Em princípio, sua posição e do MST é de respeitar a propriedade produtiva?

J. P. Stédile - Sem dúvida nenhuma, não tem sentido a desapropriação de propriedades produtivas. Qual é o sentido da reforma agrária? Ela tem um sentido econômico e um sentido social. Sentido econômico para desconcentrar a propriedade da terra. No Brasil, desapropriando as propriedades acima de $\mathbf{5 0 0}$ hectares se resolve o problema da concentração da terra. E há o sentido social, que é dar terra a quem não tem e, ao mesmo tempo, produzir. Ora, se o sujeito é grande proprietário, vamos supor, de mil hectares, mas produz, ele já está cumprindo a função social daquele bem da natureza para a sociedade. Temos que nos dedicar ao latifúndio improdutivo, que não está cumprindo sua função social, pois é um bem da natureza que deveria estar a serviço de toda a sociedade e não está. Então, o Estado, em nome da sociedade, penaliza, desapropria, recolhe aquela terra e entrega a quem vai produzir. Esse é o sentido da reforma agrária, por isso vamos desapropriar apenas os latifúndios improdutivos, para que aquela terra passe a ser produtiva. $O$ incrível é que o Incra, por determinação legal, já fez o recadastramento de todas propriedades no Brasil, seguindo o novo critério da lei agrária de 1993. Encontrou grandes propriedades improdutivas, em geral acima de mil hectares. Então, só seguindo o ditame constitucional e aplicando o cadastro do Incra, poderíamos de uma hora para outra desapropriar no Brasil 139 milhões de hectares. Isso seria a maior reforma agrária do mundo, talvez percamos para a chinesa. Não afetaria nenhuma produção porque tudo isso é improdutivo. Vai faltar família sem-terra para ocupar esses 139 milhões de hectares. Se déssemos 10 hectares a cada um, daria terra para 13 milhões de famílias sem-terra, quando, no máximo, apesar de toda polêmica estatística, só temos quatro milhões de famílias sem-terra.

\section{Pontal do Paranapanema}

ESTUDOS AVANÇADOS - Como o senhor vê a conduta do governo do Estado de São Paulo com relação ao problema de terras no Pontal do Paranapanema?

J. P. Stédile-O Pontal se transformou numa situação suigeneris porque lá se encontram 400 mil hectares de terras públicas, de propriedade do governo do Estado. $O$ governo tem a escritura dessas terras, que, ao longo dos últimos $\mathbf{5 0}$ anos, foram griladas por grandes fazendeiros, com a motivação original apenas de especulação da madeira. Ainda nos governos Carvalho Pinto e Jânio Quadros, a maior parte desses 400 mil hectares era reserva florestal. Os pequenos posseiros da região guardam placas da reserva florestal que existia. Hoje, quem vai na região, vê que lá só tem pasto. Essa é a origem do problema. O MST começou a fazer ocupações de terra para denunciar a situação. Veja: quando a lei é a favor dos pobres, eles 
demoram a aplicar; quando ocupamos uma terra particular em 24 horas o juiz dá o despejo. Ora, esses senhores estão grilando terras públicas há 40 anos e as últimas decisões judiciais foram dadas há 10 anos.

Agora, qual é a polêmica? Na mesma decisão judicial, os juízes determinaram que o governo indenize as benfeitorias desses fazendeiros. A terra não é paga, mas as benfeitorias devem ser pagas. Então, estabeleceu-se uma briga, porque 0 governo quer pagar um tanto pelas cercas e aí o fazendeiro bota o preço lá em cima e se estabelece uma outra pugna. Mas essa pugna judicial mesmo assim poderia ser discutida nos tribunais, depois que o fazendeiro entregasse a terra para o assentamento.

Depois de tanta polêmica o governo Covas baixou um decreto estabelecendo um acordo, com a seguinte proposta: todo fazendeiro que se dispuser a entregar a terra de volta para o Estado, o governo, em troca, legaliza, dependendo do tamanho da área, de 30 a 70\% da terra para o antigo grileiro. Vamos ter situações em que o sujeito, por exemplo, tem mil hectares, entrega 500 para o governo e fica com 500. Com esses 500 o governo Covas vai dar uma escritura de doação para os fazendeiros. Em princípio fomos contra isso. Por que vai dar para aquele e não para outro, já que a terra é pública? Todos os 22 milhões de paulistas poderiam dizer: "Também tenho interesse naqueles 500 hectares que são do governo". Por princípio é uma medida injusta. Mas para não dizer que o MST é radical, que só queremos conflito, quando queremos resolver de uma vez esse problema do Pontal, nós aceitamos. Qual é o problema agora? O que complica a situação do Pontal? É a lentidão do governo. De um lado, você tem 400 mil hectares de terra e, de outro, 14 mil famílias cadastradas, e o governo no meio.

O problema da tensão social aumenta porque a ação do governo é muito demorada. O que defendemos? Se o governo quer mesmo resolver o problema do Pontal, teria de fazer um mutirão de funcionários públicos, juntando agrônomos da Cati, professores da Unesp, e aí sentar com todos os fazendeiros para estabelecer um acordo. Em uma semana se resolve o problema.

Qual é a tática do governo? Chama isoladamente um fazendeiro, este senta com o secretário da Justiça, aceita, sai na porta e encontra o advogado da UDR. Este diz: "Mas você foi bobo em aceitar esse acordo por 30\%, pede 50\%". Aí ele volta lá e diz: "Não aceito mais, quero 50\%". Pronto, mais uma semana, e é assim que funciona.

Há um outro dado que poderia contribuir para a solução do problema. Fora os 400 mil hectares de terras públicas, há outros latifúndios improdutivos na região que se dedicam apenas à pecuária. $O$ Incra fez um levantamento por satélite e encontrou 80 mil hectares, de propriedade particular, que poderiam ser desapropriados. O Jungmann, em fevereiro de 1997, prometeu que em 60 dias iria desapropriar essas terras. Até agora ele não desapropriou nenhuma dessas áreas. É a mesma coisa. O problema não $\in$ ficar anunciando intenção na imprensa, pois o acampamento continua lá. 


\section{Posições políticas}

ESTUDOS AVANÇADOS - Em que medida o MST vê outras questões políticas, fora da luta direta pela reforma agrária?

J. P. Stédile-Aqui vou reivindicar nosso mestre da USP, José de Souza Martins, que desde o início do Movimento serviu como uma espécie de consultor informal, mas nem sei se ele gosta deste título. Ele sempre nos ajudou com seus escritos e palestras, para encontrarmos o melhor caminho para a reforma agrária. Uma das coisas que José de Souza Martins nos ensinou é que a reforma agrária só tem sentido se mudar realmente a estrutura de poder no Brasil, e se fizermos um movimento nacional. Se a luta ficasse localizada apenas no problema de terra, as elites assimilariam com muita facilidade e não haveria uma luta por mudança social.

A segunda coisa que ele nos ensinou é que a luta pela reforma agrária só adquiriria caráter social e político, e ajudaria a transformar a sociedade brasileira, se tivéssemos um movimento social que algutinasse e sistematizasse essas experiências e que conseguisse fazer com que o camponês passasse de sua consciência corporativa, de querer terra só para si, para uma consciência social, de compreender que mesmo tendo seu pedacinho de terra o problema não está resolvido. Porque a reforma agrária é mais ampla, refere-se à organização da agricultura como um todo. Por isso o esforço do MST em ser um movimento social que consiga que os camponeses passem daquela consciência ingênua, corporativa, para uma consciência social. Somente assim eles se transformarão em sujeitos políticos que participam da sociedade brasileira, que participam do sindicato, do partido. Essa é a nossa pregação para que os camponeses engajados no MST adquiram essa consciência.

Nosso engajamento em questões políticas, como na questão da Vale do Rio Doce, como na luta contra a reeleição, foi o reflexo, a conseqüência, de que nossa base virou cidadã. Deveria chamar a atenção se não nos envolvêssemos, se só estivéssemos preocupados com a terra. Aí seríamos meio-cidadãos.

Para exercer a cidadania plena, o cidadão tem de participar de todos os problemas da nossa sociedade. Foi isso que dissemos, inclusive ao governo, quando ele reclamou da nossa campanha contra a privatização da Vale. Nosso título de eleitor é diferente? Está escrito no nosso título que somos só eleitores para assuntos da terra? Para os outros temas da sociedade não podemos nos meter? Podemos devolver a mesma provocação e dizer: "E sociólogo da USP: por que não se preocupa em dar só aulas? Por que quer ser candidato a presidente?”.

ESTUDOS AVANÇADOS - Há por parte do MST o objetivo de uma transformação socialista no Brasil?

J. P. Stédile - Não gostamos de rótulo, pois simplifica e reduz. Não estamos preocupados se a reforma agrária é capitalista ou socialista. O que nos preocupa mesmo é entender a sociedade brasileira, identificar os principais problemas e apresentar soluções. 
Minhas motivações ideológicas são de resgatar o que significa o socialismo. Pessoalmente, em termos de valores, sou um socialista cristão. Foi na Igreja que aprendi os valores humanitários da fraternidade, igualdade, e uno a isso o socialismo, que é o resgate da igualdade e da justiça social, também na economia e no acesso aos bens. Sonhamos em construir uma nova sociedade no Brasil que consiga resolver os problemas de todos. Onde todo mundo tenha trabalho, não apenas alguns, onde todo mundo tenha casa, onde todo mundo tenha acesso à educação e não só ao $3^{\circ}$ ano primário, como agora, mas tenha acesso inclusive à universidade, onde todo mundo possa ter futuro para seus filhos, onde possa ter direito de partucipar na vida pública e não apenas nesse arremedo de democracia formal, onde o cidadão só é manipulado a votar em determinadas épocas.

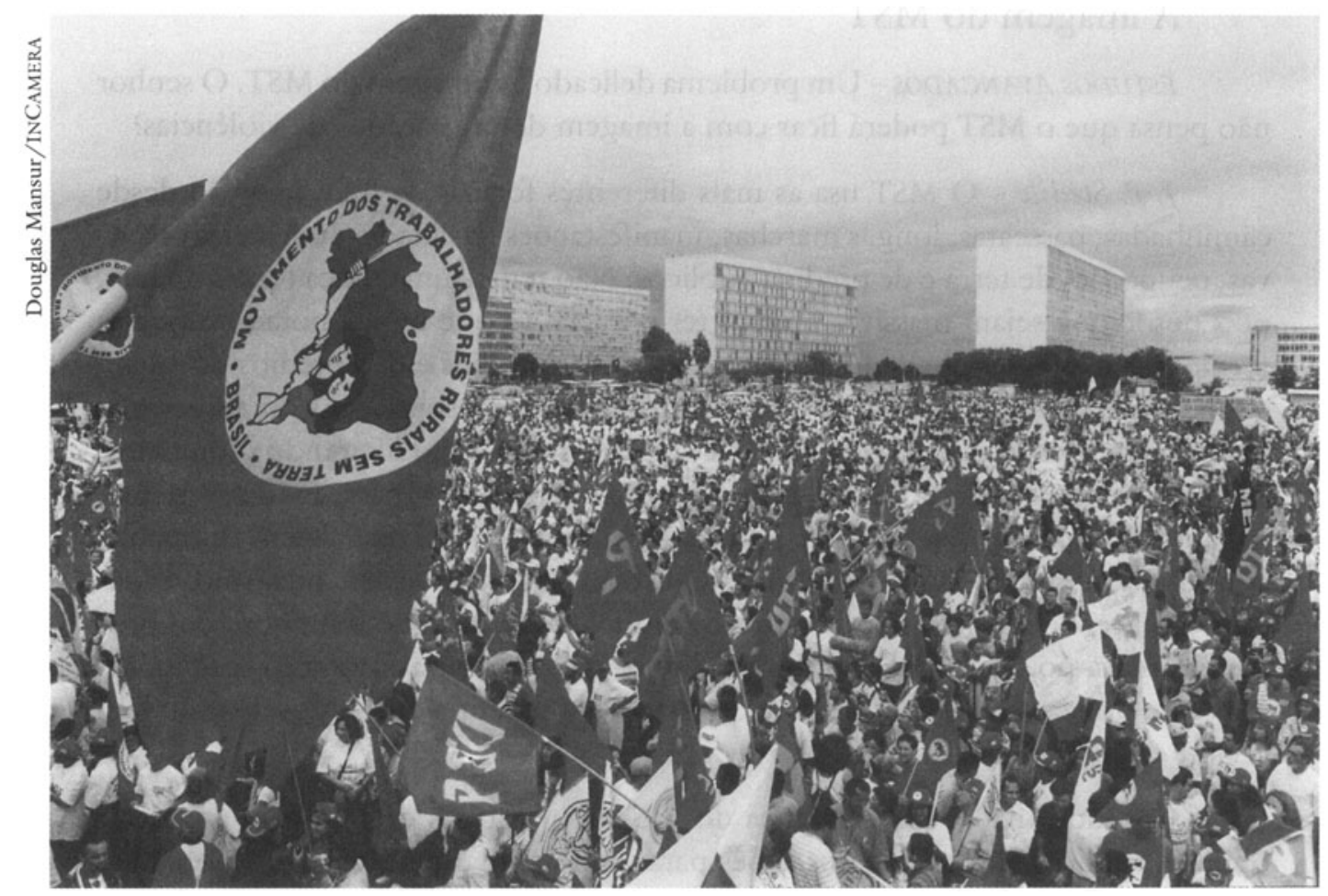

Chegada em Brasilua dos manifestantes da marcha nacional do MST, em março de 1997

ESTUDOS AVANÇADOS - Qual a ligação do MST com a Comissão Pastoral da Terra?

J. P. Stédile - Sempre tivemos vinculações com a Comissão Pastoral da Terra (CPT) e com outros setores progressistas das chamadas igrejas cristãs históricas. A CPT teve um papel importante na fundação do movimento e foi ela que fez o prımeiro trabalho de conscientização dos camponeses. De certa forma, o MST é filhote da CPT. Dificilmente os camponeses teriam adquirido consciência se a CPT não tivesse feito aquele trabalho. A CPT, lá nos primórdios de 1975 a 1984, ia para o interior fazer o trabalho de base e dizia assim: "Deus só ajuda a quem se organi- 
za, não pensem que Deus vai ajudar vocês se ficarem só rezando...". Isso motivou que os camponeses começassem a se organizar, seja no sindicato, seja em partido político, seja no MST. No início a CPT tinha uma participação mais ativa nas ocupações de terra, porque os lavradores não tinham ainda suas organizações. A partir de 1984, surgiram outros movimentos também resultantes desse trabalho. A CPT refluiu um pouco mais para o seu trabalho específico, o trabalho pastoral. Do ponto de vista doutrinário e de apoio à reforma agrária, e da contundência de suas posições, a CPT sempre teve um papel muito importante ao lado dos trabalhadores, nunca se deixou esmorecer e nunca se deixou envolver pela posições do governo, sempre foi contra a falsa propaganda do governo de que estaria fazendo a reforma agrárı no Brasil.

\section{A imagem do MST}

ESTUDOS AVANCCADOS - Um problema delicado é a imagem do MST. O senhor não pensa que o MST poderá ficar com a imagem de provocador de violências?

J. P. Stédile - O MST usa as mais diferentes formas de luta, que vão desde caminhadas, passeatas, longas marchas, manıfestações na cidade, audiências coletivas, ocupações de terra e de prédios públicos. Não temos uma única forma de luta, pois desde que sejam massivas podem ter eficácia. O que temos notado é que as formas mais eficazes têm sido as ocupações de latifúndios e dos prédios do Incra, quando a burocracia interna do órgão emperra as desapropriações ou a liberação de dinheiro. Tanto que só vem a público que eles não estão liberando o dinheiro, ou que tal desapropriação está parada, quando ocupamos o Incra. Evidentemente, pagamos um preço alto por isso. A direita e a grande imprensa fazem campanha contra nós, tentando descaracterizar essas ações como se fossem vandalismo. Pagamos um preço, mas não temos outro camınho. Acontece que tratamos com problemas reais, pois o pessoal precisa de dinheiro para fazer a plantação. Então, temos que utilizar todas as formas de pressão para garantir que o governo de fato acelere essas medidas.

Contudo, não é linha política do MST usar formas de luta para agradar a opinião pública. Nunca fizemos ações para a mídia, mas para resolver problemas concretos. O resultado é que sai na mídıa de forma positiva ou negativa, dependendo da visão de cada um. Em muitos Estados é impressionante a luta pela reforma agrária, mas a imprensa só dá bola para o Pontal. Esse ano, por exemplo, fizemos 59 ocupações de terra em Pernambuco, por causa da crise canavieira. A imprensa não relatou, porque ali o Estado de $S$. Paulo não tem correspondente, porque a TV Globo não está lá, e então não repercute. Mas o problema social do semterra é muito mais grave hoje em Pernambuco do que no Pontal do Paranapanema.

Por último, é claro que sofremos essa campanha dos setores conservadores. Por exemplo, eles vivem dizendo que fizemos reféns nos prédios do Incra. Nós pedimos aos funcionários do Incra para permanecerem nos prédios para evitar depredação e roubo. Há cinco anos ocupamos o prédio do Incra no Ceará e pedimos 
aos funcionários: "Vão para casa, vão descansar que agora nossa briga é com Brasília". Eles foram, fizemos a negociação, saímos do prédio três dias depois. Passada uma semana, o superintendente, que era do PFL, foi para a televisão dizer: "Os semterra roubaram um computador, meu casaco que estava na minha cadeira etc". Nós passamos por ladrões. Então, qual é a orientação que agora damos quando ocupamos um prédio? Peçam aos funcionários do Incra, em que a maioria é progressista, para continuar no prédio conosco, porque eles vão ser os fiscais e as testemunhas de que não mexemos num alfinete do Incra. Apenas queremos que a reforma agrária acelere.

O que a grande imprensa e o próprio Jungmann fazem? Vão para a televisão e dizem: "Estão fazendo refém". Até aconteceu um fato folclórico no Incra da Bahia, anos atrás. Fizemos essa mesma negociação e o superintendente ficou lá pacificamente, durante o dia inteiro e à noite. Era um sujeito do PFL, indicado pelo Antonio Carlos Magalhães. O Jungmann foi para a televisão e disse: "Estão fazendo refém, o meu superintendente, é um absurdo, agora é tortura psicológica". Fez toda aquela guerra. Aí pedimos ao superintendente: "Por favor, vá para a televisão e diga se o senhor é refém ou não". Ele foi para a televisão e disse: "Não, de maneira alguma sou refém, es-

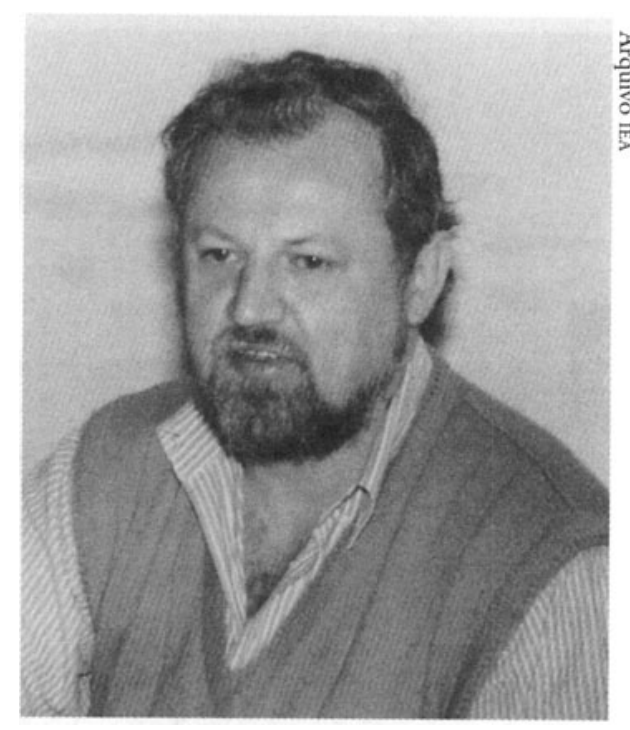

João Pedro Stédile tou aqui em cumprimento do meu dever, que é zelar pelo patrimônio público, e como sou o negociador, se saio daqui aí eles não têm com quem negociar". Sabe o que aconteceu com ele? Foi demitido pelo Jungmann porque o desmentiu publicamente, apesar de ser do PFL e não ter nenhuma ligação amistosa conosco.

Mas isso faz parte da vida. Antigamente a sociedade também olhava arrepiada as ocupações de latifúndios. "Isso é violência", dizia-se. Hoje, $89 \%$ da população apóiam a ocupação de latifúndios. Acredito que, devagarinho, a população, apesar da propaganda da direita, vai entender também qual é o verdadeiro significado de nossas ocupações de sedes do Incra.

Por último, quero aproveitar e ir para um outro assunto que havia esquecido, mas que é importante ficar registrado na revista. A direita, com freqüência, tem acusado as ocupações de terra de ilegais. Temos defendido que as ocupações de terra são legítimas, uma vez que representam a pressão popular para o governo aplicar uma lei, que é a da reforma agrária. Com isso o próprio governo concorda conosco, sabe que o movimento sem-terra é fundamental para a reforma agrária avançar. 
Mas, no mês de agosto, saiu um acórdão do Superior Tribunal de Justiça, quando julgou um habeas-corpus nosso, criando uma jurisprudência muito importante, dizendo claramente que as ocupações de terra feitas pelo MST visam a implantar a reforma agrária e não se caracterizam como esbulho possessório. Daí que não se pode criminalizar uma ocupação de terra, por não poder ser julgada pelo Código Penal. Quando ocupamos uma terra não queremos afetar o patrimônio de alguém, queremos que a reforma agrária vá para a frente. As ocupações de terra, a partir desse acórdão, passam a ser também legais, porque têm o reconhecimento do Tribunal, e as ações que fazemos são para que o governo cumpra a lei.

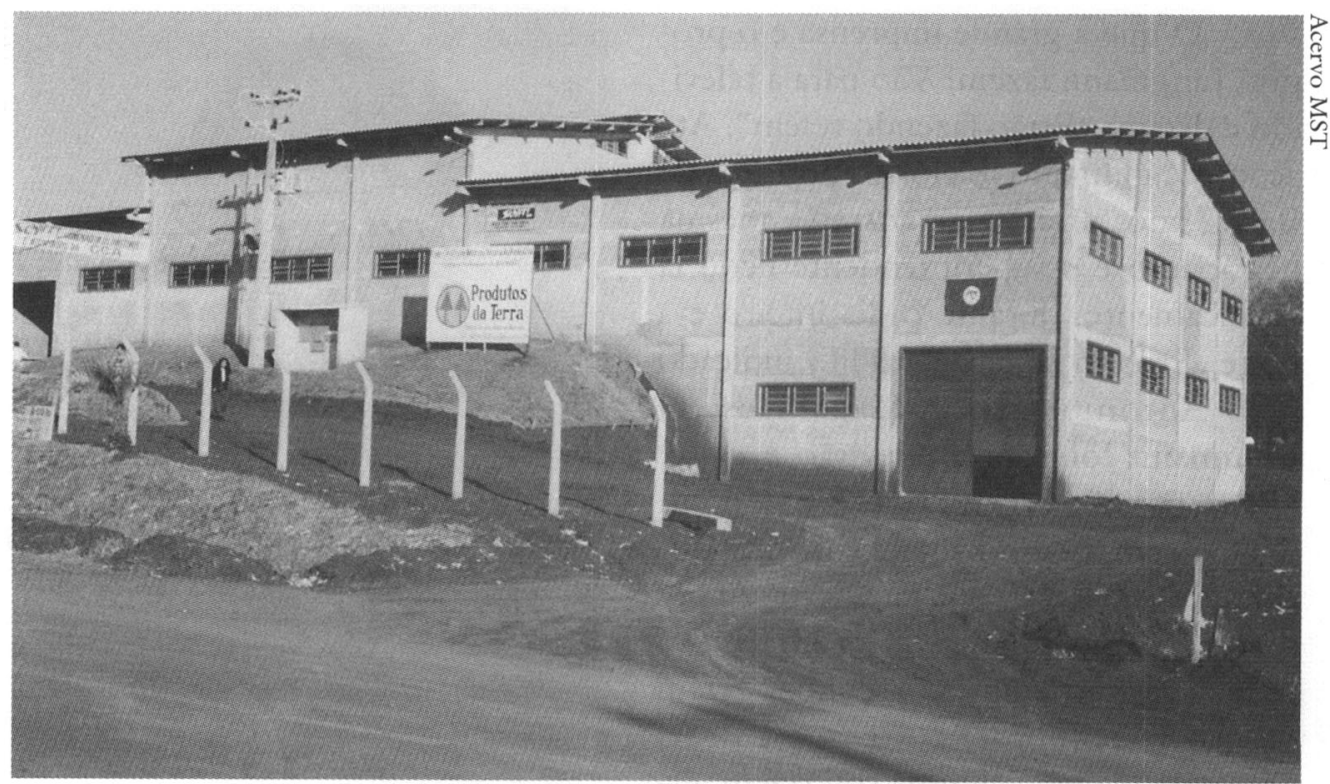

Vista da unidade de Produção da Cruateira, em Santa Maria d'Oeste, Paraná.

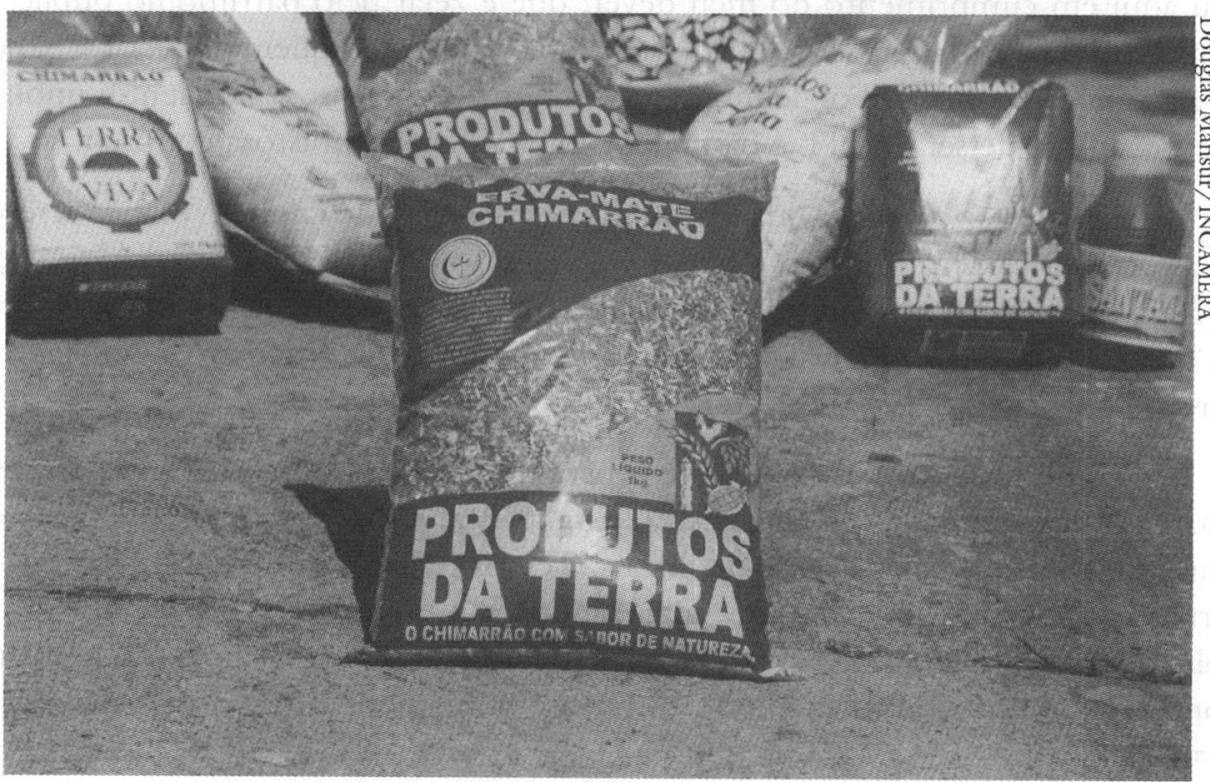

Cooperativas de assentados planejam a compra e venda de produtos. 


\section{Terras passíveis de desapropriação*}

A legislação brasileira vigente é suficiente para se implementar a reforma agrária. Não é por falta de lei que não se distribuem terras.

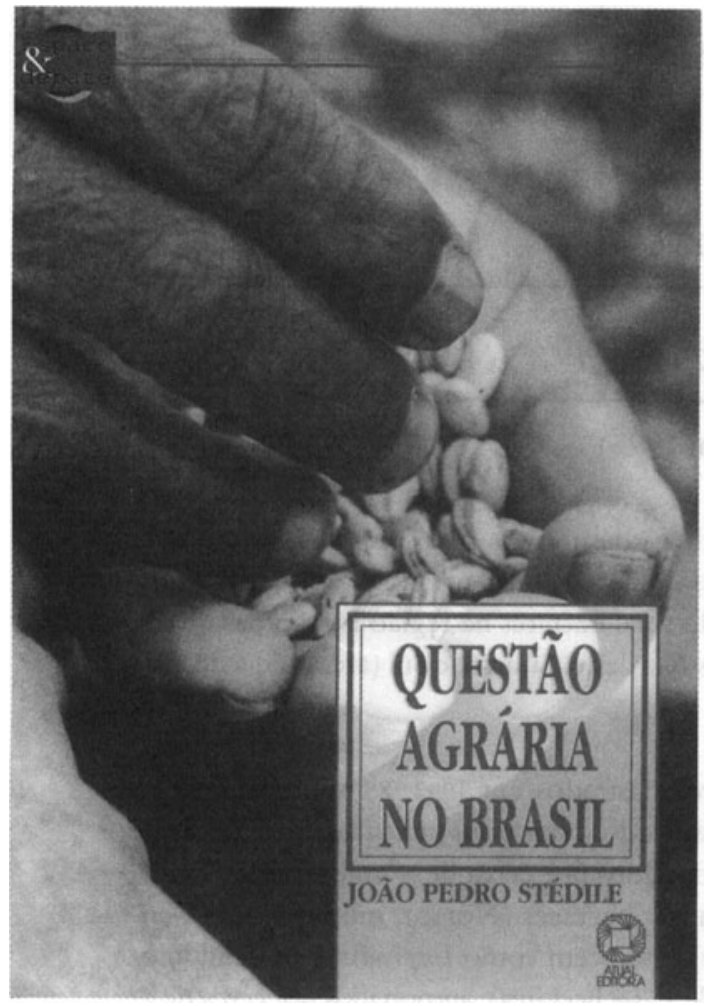

Capa do livro de João Pedro Stédile

Em 1964, o regime militar promulgou o Estatuto da Terra e, posteriormente, outras leis complementares. Em 1988, foi incorporado à Constituição o princípio da necessidade de reforma agrária. Há, inclusive, uma polêmica estabelecida. Alguns juristas consideram a atual Constituição ambígua e menos eficaz que o Estatuto da Terra; outros argumentam que a legislação atual é suficiente, e o que falta é determinação política dos governos. Afinal, a lei sempre viria depois dos fatos sociais. Mais recentemente foi promulgada a Lei Agrária, Lei Complementar $n^{\circ}$ 8.624 , que tem por objetivo facilitar a aplicação da Constituição.

José Gomes da Silva, um dos maiores especialistas na questão agrária brasileira, ex-presidente do Incra e ex-secretário de Agricultura do Estado de São Paulo, elaborou a tabela a seguir, com dados sobre a quantidade de terra que poderia ser desapropriada aplicando-se a lei em vigor. Pela tabela, seria possível desapropriar no Brasil, segundo o Estatuto da Terra, até 284 milhões de hectares, classificados, na época, como latifúndios. Com a nova Lei Agrária n ${ }^{\circ} 8.264$, de 1993, que determina a desapropriação das grandes propriedades improdutivas, o governo poderia dispor de 115 milhões de hectares que se enquadram nessa classificação. Seriam atingidos por essa lei $\mathbf{5 7 . 1 8 8}$ proprietários, correspondendo a $2,8 \%$ do total.

Com a disponibilidade de 115 milhões de hectares, tomando-se por base um módulo médio de 15 hectares, mais de cinco milhões de famílias de trabalhadores, ou seja, a totalidade dos sem-terra existentes, poderiam ser beneficiadas sem que fosse afetado nenhum hectare de terra produtiva.

\footnotetext{
* O texto e os quadros aqui publicados foram extraídos do livro Questāo agraria no Brasil, de João Pedro Stédile.
} 
Áreas que podem ser desapropriadas, segundo a lei

\begin{tabular}{|c|c|c|c|c|}
\hline Categoria & $\begin{array}{l}\text { Imóveis } \\
\text { rurais }\end{array}$ & $\begin{array}{c}\text { Área } \\
\text { (em mil } \\
\text { hectares) }\end{array}$ & $\begin{array}{c}\text { Número de } \\
\text { proprietários }^{(2)}\end{array}$ & Porcentagem ${ }^{(5)}$ \\
\hline $\begin{array}{l}\text { Latifúndios (Segundo } \\
\text { Estatuto da Terra) }\end{array}$ & 95.380 & 284.418 & 63.587 & 3,1 \\
\hline 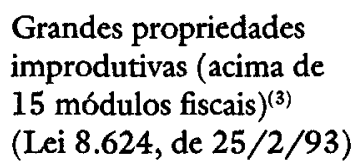 & 85.781 & 115.054 & 57.188 & 2,8 \\
\hline $\begin{array}{l}\text { Grandes propriedades } \\
\text { com limite mínimo }\end{array}$ & 70.833 & 120.975 & 47.222 & 2,3 \\
\hline
\end{tabular}

Fonte: Incra (organizado por José Gomes da Silva, em 1995).

(1) O cadastro de 1992 revelou um total de cinco milhões de imóveis rurais com 639 milhões de hectares. Destes, 1219167 umóveis com 424 milhões de hectares foram classificados como latifúndios. Tomaram-se apenas os latifúndios acima de 1500 hectares na região Norte; de um mil hectares na região Centro-Oeste; e de 500 nas regiões Nordeste, Sudeste e Sul (área média de 2604 hectares).

(2) Média de 1,5 imóvel rural por proprietário.

(3) De um total de três milhões de imóveis rurais recadastrados em 1992, 85 mil, acima de 15 módulos fiscais (grandes propriedades), foram classificados como improdutivos (área média de 1341 hectares). Esses 85 mil imb́veis rurais săo apropriados por cerca de 57 mil proprietários.

(4) Trabalhando com o limite mínimo adotado de 1500 hectares (Norte), mil hectares (Centro-Oeste) e 500 hectares (Sul, Sudeste e Nordeste), aparecem como improdutivos 70 mil imóveis rurais com 120 milhões de hectares (área média de 1708 hectares), apropriados por cerca de 47 mil proprietários.

(5) Porcentagem sobre o total de proprietários do Brasil. 
Quadro econômico comparativo da realidade do assentamento de São Joaquim, município de Teixeira Soares (PR) - 1989

\begin{tabular}{|l|l|l|}
\hline & \multicolumn{1}{|c|}{ Antes } & \multicolumn{1}{|c|}{ Depois } \\
\hline Área & 2835 hectares & 2835 hectares \\
\hline Residência dos proprietários & Curitiba & - \\
\hline Moradores & 1 família (capataz) & 107 famílias \\
\hline Lavouras & - & $\begin{array}{l}\text { Produção agrícola vendida } \\
\text { safra } 93 / 94 \\
\text { milho: } 20 \text { mil sacas } \\
\text { feijão: } 1100 \text { sacas } \\
\text { arroz: } 600 \text { sacas } \\
\text { erva-mate: } 150 \\
\text { pés árvores frutíferas: } 5 \text { mil pés }\end{array}$ \\
\hline Animais & 2 cavalos & $\begin{array}{l}\text { bovinos: } 530 \\
\text { equinos: } 600 \\
(150 \text { cavalos }) \\
\text { ovinos: } 80\end{array}$ \\
\hline Madeira & - & $\begin{array}{l}\text { Já havia sido retirada } \\
150 \text { hectares }\end{array}$ \\
\hline Benfeitorias & - & $\begin{array}{l}\text { trator: } 1 \\
\text { trilhadeiras: } 3 \\
\text { carroças } 75\end{array}$ \\
\hline Máquinas & 25 hectares & $\begin{array}{l}\text { casas com telhas: } 30 \\
\text { posto de saúde: } 1\end{array}$ \\
\hline
\end{tabular}


Importante: Nesta área o assentamento ainda não foi oficializado e por isso as famílias não receberam nenhum crédito para produção, nem recursos do governo. Mesmo assim estão produzindo alimentos, garantindo moradia, escola e atendimento à saúde.

Quadro econômico comparativo da realidade do assentamento de Novo Paraíso, município de Pitanga (PR) - 1994

\begin{tabular}{|c|c|c|}
\hline & Antes & Depois \\
\hline Área & 976 hectares & 976 hectares \\
\hline Proprietário & um deputado federal & - \\
\hline Moradores & $\begin{array}{l}4 \text { famílias de posseiros } \\
\text { (continuam como } \\
\text { assentados) }\end{array}$ & 42 famílias \\
\hline Lavouras & $\begin{array}{l}\text { só a da área que os } \\
\text { posserros cultivavam } \\
\text { por sua conta e risco }\end{array}$ & $\begin{array}{l}\text { Produção agrícola } \\
\text { vendida - safra } 93 / 94 \\
\text { milho: } 18 \text { mil sacas } \\
\text { feijão: } 1500 \text { sacas }\end{array}$ \\
\hline Animais & - & $\begin{array}{l}\text { bovinos: } 87 \\
\text { ( } 57 \text { vacas de leite) } \\
\text { ovinos: } 99 \\
\text { suínos: } 50 \\
\text { de tração: } 2\end{array}$ \\
\hline Máquinas & - & $\begin{array}{l}\text { tratores } 5 \\
\text { descascadora de arroz: } 1 \\
\text { forrageira: } 1 \\
\text { motor diesel } \\
\text { estacionário: } 1 \\
\text { moto-serra: } 1\end{array}$ \\
\hline Benfeitorias & - & $\begin{array}{l}\text { estábulos }\left(102 \mathrm{~m}^{2}\right): 2 \\
\text { chıqueiro }\left(48 \mathrm{~m}^{2}\right): 1 \\
\text { aprisco: } 1 \\
\text { galpão pré-moldado: } 1 \\
\text { secador de cebola: } 1 \\
\text { galpão de fumo: } 2 \\
\text { casa de apicultura: } 1 \\
\text { cerca: } 5260 \mathrm{~m}\end{array}$ \\
\hline
\end{tabular}




\section{A experiência do MST nos assentamentos}

A reportagem do jornalista Carlos Stegemann mostra com muito clareza como é a vida num assentamento que conseguiu organizar uma cooperativa de produção. A cooperação agrícola é um sistema bastante estimulado pelo MST junto aos assentados, pois desse modo os agricultores têm mais chances de enfrentar as dificuldades que se apresentam. Por ela entende-se a valorização das mais diversas formas de ajuda entre os agricultores, com relação a uma divisão do trabalho, à compra coletiva de máquinas e à construção de benfeitorias, por exemplo. Tais formas adquirem diferentes características, de acordo com a cultura da região e o grau de desenvolvimento econômico que os assentados lograram. Assim, em muitos assentamentos, o trabalho coletivo restringe-se apenas ao plantio e à colheia, o chamado mutirão. Em outros, há associações formais, responsáveis pela compra de máquinas, insumos e caminhões, de forma coletiva. Existem ainda cooperativas que planejam a compra e a venda de produtos. A prática da cooperação agrícola apresenta a sua forma mais complexa de desenvolvimento quando os assentados organizam uma CAP (Cooperação de Produção Agropecuária), que reúne coletivamente a propriedade da terra, a organização da produção, a construção das casas, etc. Existem hoje no Brasil cerca de $42 \mathrm{CAPs}$, distribuídas por vários Estados (veja quadro a seguir). Se alguma delas for próxima à sua cidade, recomendo uma visita para conhecê-la.

Cooperativas de Produção Agropecuária - CPAs

\begin{tabular}{|l|l|r|}
\hline \multicolumn{1}{|c|}{ Município - Estado } & \multicolumn{1}{|c|}{ Assentamento } & No $^{\text {o }}$ sócios \\
\hline Alcobaça (BA) & Projeto 4045 & 30 \\
Arataca (BA) & Terra Vista & 100 \\
Prado (BA) & $1^{\circ}$ de Abril & 28 \\
Vitóna da Conquista (BA) & Fazenda Amaralına & 128 \\
Canindé (CE) & Vitória & 56 \\
Itarema (CE) & Lagoa do Mineiro & 140 \\
Madalena (CE) & 25 de Maio & 80 \\
Monsenhor Tabosa (CE) & Santana & 54 \\
Ecoporanga (ES) & Vale Ouro & 48 \\
Nova Venécia (ES) & Pip Nuk & 40 \\
São Gabriel da Palha (ES) & 13 de Maio & 45 \\
São Mateus (ES) & Vale da Vitória & 65 \\
Vitória do Mearım (MA) & Vila Diamante & 72 \\
Anastácio (MS) & São Manoel & 28 \\
Arcoverde (PE) & Pedra Vermelha & 30 \\
Riberrão (PE) & Serrinha & 20 \\
Bonito (PE) & Serra Quilombos & 30 \\
Timbaúba (PE) & Panorama & 20 \\
Lindoeste (PR) & Verdum & 20 \\
Paranacity (PR) & Santa Maria & 37 \\
Querência do Norte (PR) & Portal do Tigre & 31 \\
\hline
\end{tabular}




\begin{tabular}{|l|l|r|}
\hline Município - Estado & Assentamento & No de sócios \\
\hline Pitanga (PR) & Cascata & 20 \\
Pitanga (PR) & Otto Cunha & 54 \\
Charqueadas (RS) & 30 de Maio & 58 \\
Eldorado Sul (RS) & IRGA & 46 \\
Hulha Negra (RS) & Conq. de Fronteıra & 38 \\
Júlio de Castllhos (RS) & Nova Ramada & 52 \\
Pontão (RS) & Fazenda Annoni & 15 \\
Salto do Jacuí (RS) & Rincão do Ivaí & 54 \\
Novo Barreiro (RS) & Peq. Agricultores & 650 \\
Constantuna (RS) & Peq. Agricultores & 700 \\
Trindade do Sul (RS) & Trindade do Sul & 30 \\
Três Passos (RS) & Peq. Agricultores & 100 \\
São Pedro (RS) & Padre Josimo & 45 \\
Pontão (RS) & Fazenda Annonı & 70 \\
Piratini (RS) & Conquista Liberdade & 46 \\
Nova Santa Rita (RS) & Capela & 60 \\
Santana do Livramento (RS) & Liberdade no Futuro & 54 \\
Abelardo Luz (SC) & Volta Grande & 77 \\
Abelardo Luz (SC) & Papuã II & 100 \\
Campos Novos (SC) & 30 de Outubro & 78 \\
Dionísio Cerqueira (SC) & Conq. da Fronteıra & 58 \\
Itabera (SP) & Vó Aparecida & 58 \\
Itapeva (SP) & Pirituba & 40 \\
Promissão (SP) & Pad. Josimo Tavares & 80 \\
\hline
\end{tabular}

Cooperativas Regionais

\begin{tabular}{|c|c|c|c|c|}
\hline UF & Município & Sigla & Cooperativas & Sócios \\
\hline PR & Cantagalo & Coagri & $\begin{array}{l}\text { Coop. de Trab. Rurais e Ref. } \\
\text { Agr. do Centro-Oeste/PR }\end{array}$ & 1328 \\
\hline PR & Lindoeste & Coara & $\begin{array}{l}\text { Coop. Comerc. e Ref Agrária do } \\
\text { Oeste do PR Ltda. }\end{array}$ & 90 \\
\hline RS & Hulha Negra & Cooperal & Coop. Regional dos Assentados & 870 \\
\hline RS & Sarandi & Coanol & Coop. Agrícola Novo Sarandi Ltda. & 880 \\
\hline SC & Abelardo Luz & Cooperjus & Coop. Regional de Comerc. Justino Draszevski & 92 \\
\hline SC & Matos Costa & Coopercon & $\begin{array}{l}\text { Coop. Regional de Comerc. } \\
\text { Nova Conquista Ltda. }\end{array}$ & 192 \\
\hline RS & Hulha Negra & Cooptil & Coop. de Prod. Trabalho Integração & 304 \\
\hline RS & Porto Alegre & Camasl & Coop Agrop. Mista de Ação Integrada & 98 \\
\hline SP & Pontal & Cocamp & Coop. de Comercialızação do Pontal & 300 \\
\hline PI & São João & Comasjopi & Coop. Mista dos Assentados de São João Piauí & 130 \\
\hline
\end{tabular}


Os diferentes fatores que influenciam a produtividade dos assentamentos e a sua rentabilidade, como foi relatado na reportagem, podem ser resumidos basicamente nos seguintes:

Fatores objetivos: são as reais condições que os assentados possam ter com relação a terras férteis, próximas ao mercado consumidor, e a possibilidade de obtenção de crédito-capital, com o intuito de realizar investimentos e desenvolver a produção. Daí concluímos que não basta ter a terra; é preciso obter recursos do crédito rural, para que se possa investir em equipamentos, máquinas e organizar a produção.

Fatores subjetivos: são as condições das próprias famílias assentadas no que tange à tradição cultural de desenvolvimento de atividades comunitárias, ao grau de consciência e de organização social e ao nível de capacitação formal que possuem. Esses fatores também influenciam decisivamente a capacidade de organização das diferentes formas de cooperação agrícola nos assentamentos.

Os agricultores do assentamento de Conquista da Fronteira são apenas um exemplo de que a realidade rural brasileira poderá vir a ser muito diferente da atual, se a questão agrária no Brasil se tornar efetivamente uma prioridade dos governantes e de toda a sociedade brasileira. 